\section{Commentary: Aortic valve annuloplasty: The true and the false}

Davide Pacini, $\mathrm{MD}, \mathrm{PhD}$, and

Giacomo Murana, MD, PhD

During the past decade, valve-preserving root replacement has been increasingly adopted and standardized for patients with ascending aortic dilatation. ${ }^{1,2}$ This led to the introduction in European guidelines ${ }^{3}$ of aortic valve repair, using the reimplantation or remodeling with aortic annuloplasty technique, being recommended as class I (level C) in young patients with aortic root dilation and tricuspid aortic valves when performed by experienced surgeons. However, there are favorable conditions that predict durable outcomes and other factors that could suggest a higher incidence of aortic reinterventions.

In the interesting review article by Federspiel and colleagues, ${ }^{4}$ the authors present a summary of different aortic annuloplasty techniques performed in patients undergoing valve and root repair. They critically describe current options and different aspects of this fascinating procedure. Based on that acquired knowledge, one might condense the possibility of sparing the aortic valve in 2 words: indication and expertise.

The key to reproducing a successful aortic valve-sparing operation is specific recommendations. ${ }^{5}$ The first step to a successful repair is accurate and meticulous assessment of root anatomy. Preoperative echocardiography can describe valve morphology, quantify aortic regurgitation and evaluate its mechanisms, determine the aortic direction jet

\footnotetext{
From the Cardiac Surgery Department, S Orsola Hospital, University of Bologna, Bologna, Italy.

Disclosures: The authors reported no conflicts of interest.

The Journal policy requires editors and reviewers to disclose conflicts of interest and to decline handling or reviewing manuscripts for which they may have a conflict of interest. The editors and reviewers of this article have no conflicts of interest.

Received for publication Jan 9, 2021; revisions received Jan 9, 2021; accepted for publication Jan 13, 2021; available ahead of print Jan 19, 2021.

Address for reprints: Davide Pacini, MD, PhD, Cardiac Surgery Department, S Orsola Hospital, University of Bologna, Via Massarenti 9, 40138, Bologna, Italy (E-mail: davide.pacini@unibo.it).

JTCVS Techniques 2021;7:105-6

2666-2507

Copyright (C) 2021 The Authors. Published by Elsevier Inc. on behalf of The American Association for Thoracic Surgery. This is an open access article under the CC BY-NCND license (http://creativecommons.org/licenses/by-nc-nd/4.0/).

https://doi.org/10.1016/j.xjtc.2021.01.013
}

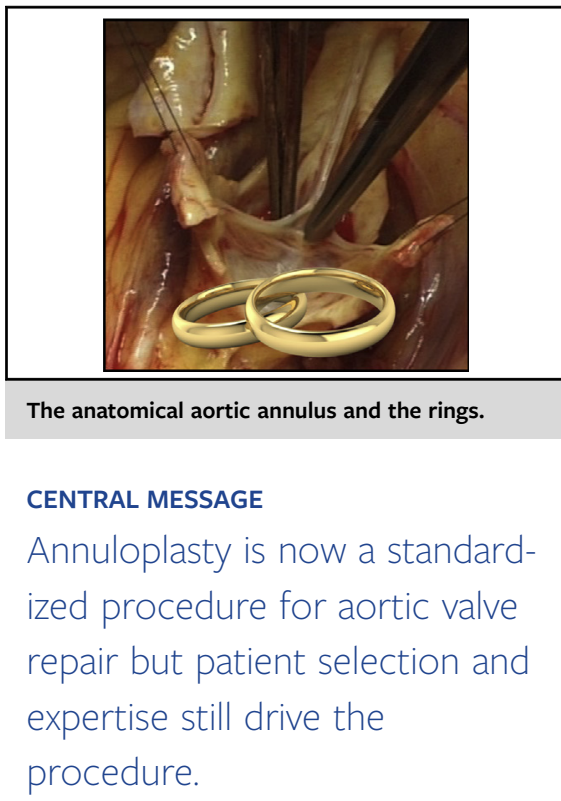

(eg, central or eccentric), define the morphology of the aorta, and determine the feasibility of valve-sparing aortic surgery or valve repair.

The second step is experience inside the operative theater. Different concepts of annuloplasty have been proposed, including internal and external rings, suture annuloplasty, subcommissural suture, and sinotubular junction remodeling. We know that ring annuloplasty provides a more effective reduction of aortoventricular diameters compared with subcommisural plication; however, there is little objective evidence regarding superiority of any single technique over another. Even less evidence is available regarding pros and cons of various approaches for certain pathologies. Therefore, the best mode of application of a device (external vs internal ring), type of material, sizing, and all of the other adjunctive procedures performed on the aortic root make the difference to effectively stabilize the aortoventricular junction and obtain durable repair.

An untruth that abounds in the field of aortic annuloplasty is regarding the absence of acute drawbacks. This procedure adds complexity to aortic valve repair and severe complications may occur even in expert hands. There are reported case series of coronary distortion leading to infarction, fistula between the aorta and the right ventricle, interference with cusp mobility, conduction system disturbances, and severe bleeding. Long-term failure has been also described, especially for internal rings because prosthetic material close to cusp tissue may lead to inflammatory changes and cusp restriction. ${ }^{6}$ It is also wrong to say that aortic annuloplasty is the only way to stabilize the annulus in cases 
of root dilatation because the reimplantation technique can solve the problem in the same way.

The use of aortic valve annuloplasty has evolved from an occasional procedure to a reproducible treatment option; however, clear recommendations are not available and we all should keep in mind to choose the right patient for the ring and then to find the ring that fits the patient.

\section{References}

1. David TE, Armstrong S, Manlhiot C, McCrindle BW, Feindel CM. Long-term results of aortic root repair using the reimplantation technique. J Thorac Cardiovasc Surg. 2013;145(3 Suppl):S22-5.
2. Aicher D, Fries R, Rodionycheva S, Schmidt K, Langer F, Schafers HJ. Aortic valve repair leads to a low incidence of valve-related complications. Eur J Cardiothorac Surg. 2010;37:127-32.

3. Baumgartner H, Falk V, Bax JJ, De Bonis M, Hamm C, Holm PJ. 2017 ESC/ EACTS guidelines for the management of valvular heart disease. Eur Heart J. 2017;38:2739-91.

4. Federspiel J, Ehrlich T, Abeln K, Schafers HJ. Aortic annuloplasty: subcommissural, intra-annular suture techniques, external and internal rings. J Thorac Cardiovasc Surg Tech. 2021;7:98-102.

5. Murana G, Pacini D. Mini or full sternotomy for aortic valve repair? A systematic review of the literature. J Cardiovasc Surg (Torino). 2021;62:19-24.

6. Lansac E, Di Centa I, Sleilaty G, Lejeune S, Khelil N, Berrebi A, et al. Long-term results of external aortic ring annuloplasty for aortic valve repair. Eur J Cardiothorac Surg. 2016;50:350-60. 